\title{
Identification Phenolic and Biological Activities of Methanolic Extract of Date Palm Pollen (Phoenix dactylifera)
}

Mohamed H M Abed El-Azim*, Amani M D El-Mesalamy, Fathy A Yassin and Salam A Khalil

Department of Chemistry, Faculty of Science, Zagazig University, Egypt

\begin{abstract}
Pollen of the date palm (DPP) has been used for long time as a traditional Egyptian herbal medicine forimproving male and female fertility. The chemical investigation of date pollen resulted from polar solvent. Six compounds which were identified as Caffeic Acid, Gallic Acid, Coumaric Acid, Chlorogenic Acid, Catchinand Quercetin. Also in this work represent the impact polar extract on biological activity;Antibacterial activity was done against six species pathogenic bacteria, it has a strong value at $22 \mathrm{~mm}$ inhibition zone with Staphylococcus Epidermises. Antifungal activity was done against two species pathogenic fungi, the extract and ketoconazole have the value with the two species. Finally the extract was tested against three human cell lines, and the results showed that it has cytotoxic activity against all cell lines.
\end{abstract}

Keywords: Phoenix dactylifera, Antibacterial; Antifungal; Cytotoxic activity

\section{Introduction}

Date palm (Phoenix dactylifera L.,Palmae) is native to the Middle East region over centuries ago [1]. In Folkloric practice, date represents an essential meal in some Arab area Miller et al., [2] and Al-Qarawi et al., [3]. The date palm (Phoenix dactylifera) is dioeciously, medium-sized tree with pinnate leaves containing about 150 leaflets having spines on the petiole. It consists of small yellowish flowers attached directly to the spikelet's which develop into fruits [4]. There has been a tremendous interest in this plant as evidenced by the voluminous work in last few decades. Therefore, we aimed to compile an up to date of Phoenix dactylifera that covers its traditional and folk medicine uses, phytochemistry and pharmacology including various preclinical and clinical studies [5]. Phytochemically the whole pollen contains carbohydrates, alkaloids, steroids, flavonoids, vitamins and tannins. The phenolic profile of the plant revealed the presence of mainly cinnamic acids (ferulic, sinapic and coumaric acids and their derivatives, such as 5-o-caffeoylshikimic acid also called as dactyliferic acid), flavonoid glycosides (luteolin, methyl luteolin, quercetin, and methyl quercetin), flavanols (catechin, epicatechin) Four free phenolic acids (protocatechuic acid, vanillic acid, syringic acid, and ferulic acid) and nine bound phenolic acids (gallic acid, protocatechuic acid, p-hydroxybenzoic acid, vanillic acid, caffeic acid, syringic acid, p-coumaric acid, ferulic acid, and o-coumaric acid) were tentatively identified [5]. Also another study evaluated the protective effects of Phoenix dactylifera pollen grains on liver and heart arteries in male rats fed with diet supplemented with different concentrations of date palm pollen grains $(0.0 \%, 2.0 \%$ and $4.0 \%)$ [6]. The aim of our research is to identify the phenolic compounds found in methanolic extract and also study some of the biological effects of the extraction some types of bacteria, fungi, and three types of human cancers.

\section{Materials and Methods \\ Collection of plant material}

Date Palm pollen was collected in March (2012) from Sharkyia Governorate, Egypt. Some explants of palm pollen (Phoenix dactyliferaL.) were collected and kept in a refrigerator at $4^{\circ} \mathrm{C}$ and were identified by botany department, Faculty of Science, Zagazig University.

\section{Material for Antimicrobials}

The bacterial and fungal strains were personally obtained from the microbiology Lab, Botany Department, Faculty of Science, Zagazig University. Bacterial species tested were (Escherichia Coli, Klebsiella, Staphylococcus Epidermidis, Bacillus Cereus, Micrococcus Luteus and Staphylococcus Aureus). And fungal species were (Candida Albicans and Aspergillus Niger) [7].

\section{Materials for cytotoxic activity}

Human tumor cell lines: [HELA (Cervical carcinoma cell line), MCF7 (breast carcinoma cell line) and CACO (intestinal carcinoma cell line)] [8].

\section{Chromatography}

\section{Paper Chromatography}

Sheets of Whatman paper No 1 or 3 MM were used for twodimensional, comparative or preparative paper chromatography[9].

\section{Column Chromatography}

The separation of the phenolic and flavonoid components was performed by column fractionation of the extract or its fractions on one of the following stationary phases as stated in each case. A-Polyamide powder, polyamide 6-S for CC, Riedel-De Haen AG, seelze-Hannover, Germany.B-Sephadex LH-20, (25-100 $\mu \mathrm{m})$, Pharmacia fine chemicals.

*Corresponding author: Mohamed H.M. Abed El-Azim, Department of Chemistry Faculty of Science, Zagazig University, Egypt, Tel: 00201067653545; E-mail: mhmsm01213@yahoo.com

Received January 06, 2014; Accepted February 02, 2015; Published February 09, 2015

Citation: Abed El-Azim MHM, El-Mesalamy AMD, Yassin FA, Khalil SA (2015) Identification Phenolic and Biological Activities of Methanolic Extract of Date Palm Pollen (Phoenix dactylifera). J Microb Biochem Technol 7: 047-050. doi:10.4172/1948-5948.1000180

Copyright: (C) 2015 Abed El-Azim MHM, et al. This is an open-access article distributed under the terms of the Creative Commons Attribution License, which permits unrestricted use, distribution, and reproduction in any medium, provided the original author and source are credited 


\section{Physical Test}

\section{UV-Spectroscopic analysis} [10].

Investigated material and UV measurements were then carried out

\section{Ultra-violet Spectrophotometric analysis}

Chromatographically, pure materials dissolved in analytically pure methanol were subjected to UV spectrophotometric investigation in $4 \mathrm{ml}$ capacity quartz cells Zeiss spectrometer PMQ-II. In case of flavonoids, $\mathrm{AlCl}_{3}, \mathrm{AlCl}_{3} / \mathrm{HCl}$, fused $\mathrm{NaOAc} / \mathrm{H}_{3} \mathrm{BO}_{3}$ and $\mathrm{NaOMe}$ reagents were separately added to methanolic solution of the investigated material and UV measurements were then carried out.

\section{NMR Spectroscopic analysis}

${ }^{1} \mathrm{H}$ chemical shefts $(\delta)$ were measured in ppm, relative to dmso - d6 and converted to TMS scale.

\section{Nuclear magnetic resonance spectroscopic analysis}

JeolECa $500 \mathrm{MHz}$ NMR Spectrometer at $500 \mathrm{MHz}$, (Institute Fur Chemie, Humboldt Universitätzu Berlin, Germany). ${ }^{1} \mathrm{H}$ chemical shifts were measured in ppm, relative to TMS and ${ }^{13} \mathrm{C}$ NMR chemical shifts to DMSO-d6 and converted to TMS scale by adding 39.5. Typical conditions: spectral width $=8 \mathrm{KHz}$ for $1 \mathrm{H}$ and $30 \mathrm{KHz}$ for $13^{\circ} \mathrm{C}, 64 \mathrm{~K}$ data points and a flip angle of $45^{\circ} \mathrm{C}$.

\section{Mass spectroscopic analysis}

The isolation pure compounds were subjected (FAB-MS).

\section{Mass spectrometric analysis}

The isolated pure compounds were subjected, in most cases to Fast Atom Bombardment (positive and negative) mass spectroscopic analysis (F AB-MS) on MM $7070 \mathrm{E}$ spectrometer (VG analytical). Some other compounds were subjected to electron spray ionization mass spectroscopic analysis (ESI-MS) a Varian Mat1 12-ET Spectrometer. All measurements were carried out at Institute Fur Chemie, Humboldt Universitatzu Berlin, Germany.

\section{Methods}

\section{Preparation of extracts}

The yellowish powder pollen was extracted exhaustively with petroleum ether, diethyl ether and methanol (according to polarity). For each extraction the powder was left $24 \mathrm{hrs}$, in a Soxhlet apparatus. After that the methanolic extract was concentrated under vacuum and left the extract for overnight. This yielded a gummy solid which was separated by filtration. The methanolic filtration was shown by paper chromatography used two-dimensional (TDPC), comparative or preparative paper chromatography followed by column chromatography to determine phenolic and flavonoids compounds [10].

\section{Methods of antibacterial activity}

The antibacterial activity was studied by using cup plate agar diffusion method by measuring diameter of zone of inhibition in $\mathrm{mm}$. The extract was tested at the concentration of $200 \mathrm{ppm}$ in 5\% DMF. The solution was poured in the cup/well of bacteria seeded agar plates. The plates were incubated at $37^{\circ} \mathrm{C}$ for 24 hours for $E$. coli where the plates of other bacteria species were incubated at $27 \pm 2^{\circ} \mathrm{C}$ for 24 hours.
The activity was reported by measuring the diameter for zone of inhibition in mm. Ciprofloxacin was used as standard drug for antibacterial activities. Nutrient agar was employed as culture medium and DMSO were used as solvent.

\section{Methods of antifungal activity}

Antifungal activity was screened for the newly separated samples. The cup plate method was employed to study the preliminary antifungal activity of Candida Albicans and Aspergillus Niger. The extract was dissolved in $5 \mathrm{ml}$ of Dimethyl Sulfoxide $(1000 \mu \mathrm{g} / \mathrm{ml})$ Volume and $1 \mathrm{mg} / \mathrm{ml}$. Ciprofloxacin was used as standard drug (50 and $100 \mu \mathrm{g} / \mathrm{ml}$ ) and dimethyl sulfoxide as a control. The observed zone of inhibition was measured in $\mathrm{mm}$.

Methods of antitumor activity: Potential cytotoxicity of the extract was tested using the method of Skehan et al., [11]. Cells were plated in 96-multiwell plate (104 cells/well) for $24 \mathrm{hrs}$. Before treatment with the extract allow attachment of cell to the wall of the plate. Different concentrations of the extract under test $(50,100,125,250$ and $500 \mu \mathrm{g} / \mathrm{ml}$ ) were added to the cell monolayer. Triplicate wells were prepared for each individual dose. Monolayer cells were incubated with the extract for $48 \mathrm{hrs}$ at $37^{\circ} \mathrm{C}$ and atmosphere of $5 \% \mathrm{CO}_{2}$. After $48 \mathrm{hrs}$; cells were fixed, washed and stained with Sulforhodamine B strain. Excess strain was washed with acetic acid and attached strain was recovered with Tris EDTA buffer. Color intensity was measured in an ELISA reader. The relation between surviving fraction and extract concentration is plotted to get the survival curve of each tumor cell line after the specified compound [7].

\section{Results}

\section{Structure elucidation of phenolic compounds in methanol extract}

Two dimensional paper chromatography of the extract was applied on What man paperNo 1, irrigated inthe solvent system $6 \%$ (acetic acidWater) (HOAc-6), followed by butanol: acetic: water (4:1:5) revealedthe presence ofmainly six phenolic compounds,corresponding spots gave positive response towardsFeCl3 spray reagent, some of which appeared under UV light as dark purple spots which turned orange or lemon yellow or reddish orange when fumed with ammonia vapor.

Investigation of the phenolic compounds was done by fractionation of the extract over polyamide column chromatography and elution with methanol/bidistilledwater. Thenit was subjected to re-chromatography for several times led to the separation of six pure phenolic compounds. The structure of these compounds was confirmed by comparison of their physical and spectral data with those of reported compounds.

Caffeic acid: $-\mathrm{R}_{\mathrm{f}}$ values (x 100): 25 (H2O), 45 (HOAC-6\%), 81 (BAW). UV Spectral Data: MeOH 218, 245, 298, 325. ${ }^{1} \mathrm{H}-\mathrm{NMR}$ Spectral Data (DMSO-d $) \delta(\mathrm{ppm}): 6.2(\mathrm{~d}, \mathrm{~J}=16 \mathrm{~Hz}, \beta-\mathrm{H}), 6.76(\mathrm{~J}=7.5 \mathrm{~Hz}$, $5-\mathrm{H}), 6.88(\mathrm{dd}, \mathrm{J}=7.5 \mathrm{~Hz}$ and $\mathrm{J}=2.5 \mathrm{~Hz}, 6-\mathrm{H}), 6.98(\mathrm{~d}, \mathrm{~J}=2.5 \mathrm{~Hz}, 2-\mathrm{H})$, $7.48(\mathrm{~d}, \mathrm{~J}=16 \mathrm{~Hz}, \mathrm{a}-\mathrm{H})$.

Gallic acid: $\mathrm{R}_{\mathrm{f}}$ values (x100): $44\left(\mathrm{H}_{2} \mathrm{O}\right), 55(\mathrm{HOAc}-6), 72(\mathrm{BAW})$, UV (MeOH): $\lambda_{\max }=272 \mathrm{~nm},{ }^{1} \mathrm{H}-\mathrm{NMR}\left(\mathrm{DMSO}-\mathrm{d}_{6}\right): \delta 6.98(\mathrm{~s}, 2 \mathrm{H}, \mathrm{H}-2$ and H-6). ${ }^{13} \mathrm{C}-\mathrm{NMR}$ (DMSO-d $): \delta 120.6$ (C-1), 108.8 (C-2 and C-6), 145.5(C-3 and C-5), 138.1(C-4), 167.7(C=O).Ms (m/z): $170.9\left[\mathrm{M}^{+}+1\right.$, 5.1\%], $169.0\left[\mathrm{M}^{+}-\mathrm{H}, 100 \%\right.$, ion A], $167.9\left[\mathrm{M}^{+}-\mathrm{H}_{2}, 63.9 \%\right], 153\left[\mathrm{M}^{+}-\mathrm{OH}\right.$, 11.2\%], 145 [ion $\mathrm{A}-\mathrm{C}_{2}, 3.5 \%$ ], 139 [ion A-HCHO, 11.3\%], 126 [ $\mathrm{M}^{+}-\mathrm{CO}_{2}$, 6.5\%] and 123 [ion A-HCOOH, 27.1\%]. Anal. Calcd for $\mathrm{C}_{7} \mathrm{H}_{6} \mathrm{O}_{5}$ (170.02): C, 49.42; H, 3.55; O, 47.02. Found: C, 49.50; H, 3.30; O, 47.20. 


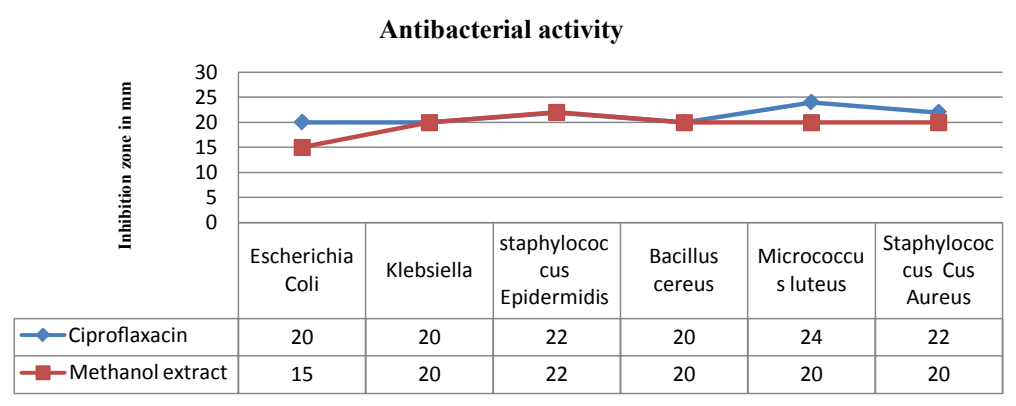

Figure 1: Antibacterial activity for date palm pollen extract.

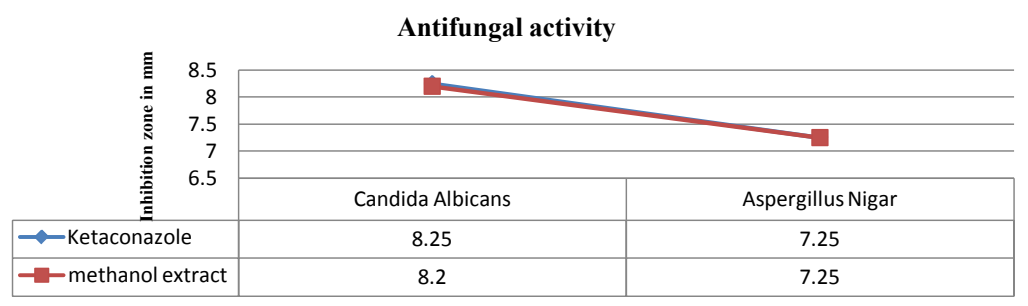

Figure 2: Antifungal activity for date palm pollen extract.

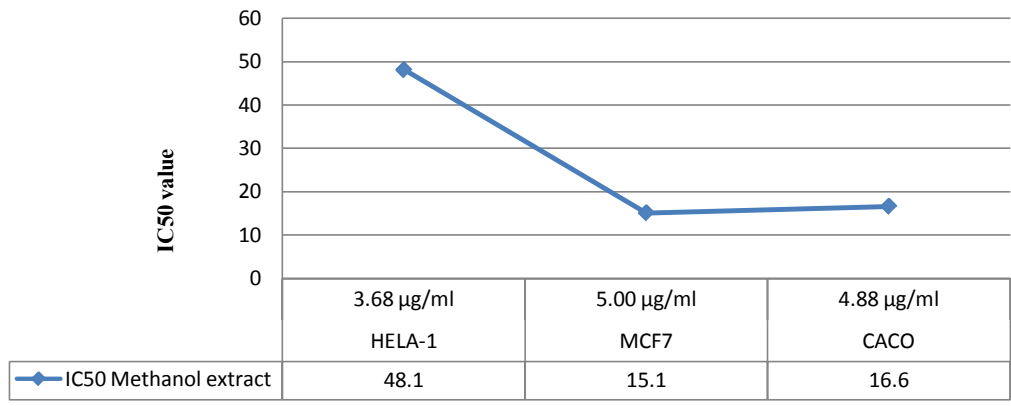

Figure 3: IC50 value of the different cell lines of the methanolic extract of date palm pollen.

Catechin: $\mathrm{R}_{f}$ values (x 100): 0.33 (H2O), 0.54 (HOAC-6), 0.60 (BAW), UV Spectral data: $\lambda_{\max }(\mathrm{nm})=278{ }^{1} \mathrm{H}-$ NMR Spectral Data $\left(\right.$ DMSO-d $\left._{6}\right) \delta(\mathrm{ppm}): 4.51(\mathrm{~d}, \mathrm{~J}=7.3, \mathrm{H}-2), 3.84(\mathrm{~m}, \mathrm{H}-3) 2.38(\mathrm{ax}, \mathrm{dd}$, $\mathrm{J}=16.0,7.9, \mathrm{H}-4), 2.68$ (eq, dd, J=16.0, 5.3, H-4), 5.90 (d, J=2.2, H-6), 5.72 (d, J=2.2, H-8),6.74 (d, J=1.9, H-2'), 6.7 (d, J=8, H-5'), 6.61 (dd, $\left.\mathrm{J}=8,1.9, \mathrm{H}-6^{\prime}\right) .{ }^{13} \mathrm{C}-\mathrm{NMR}$ Spectral Data $\left(\mathrm{DMSO}-\mathrm{d}_{6}\right): \delta(\mathrm{ppm}) 81.0(\mathrm{C}-$ 2), 66.4 (C-3), 27.7(C-4), 156.1 (C-5), 95.3 (C-6), 156.4 (C-7), 94.0 (C8), 155.3 (C-9), 99.2 (C-10), 130.7 (C- 1'), 114.5 (C-2'), 144.8 (C-3'), 144.8 (C- 4'), 115.1 (C-5'), $118.4\left(\mathrm{C}-6^{\prime}\right)$

$\rho$-Coumaric acid: $\mathbf{R}_{\mathrm{f}}$ values (x100): $43\left(\mathrm{H}_{2} \mathrm{O}\right), 45$ (HOAC-6\%), 90 (BAW).UV (MeOH): $\lambda_{\max }=266,310 \mathrm{~nm}, \mathrm{UV}(\mathrm{MeOH}+\mathrm{NaOMe})$ : $\lambda_{\max }=228,333 \mathrm{~nm},{ }^{1} \mathrm{H}-\mathrm{NMR}\left(\mathrm{DMSO}-\mathrm{d}_{6}\right): \delta 6.2(\mathrm{~d}, \mathrm{~J}=15 \mathrm{~Hz}, \mathrm{H}-\alpha), 6.72(\mathrm{~d}$, $\mathrm{J}=8 \mathrm{~Hz}, \mathrm{H}-3$ and H-5), 7.32 (d, J=8 Hz, H-2 and H- 6), $7.52(\mathrm{~d}, \mathrm{~J}=15 \mathrm{~Hz}$, $\mathrm{H}-\beta)$.Anal. Calcd for $\mathrm{C}_{9} \mathrm{H}_{8} \mathrm{O}_{3}$ (164.16): C, 65.85; H, 4.91; O, 29.24 . Found: C, 65.80; H, 4.80; O, 29.40.

Quercetin: $\mathrm{R}_{\mathrm{f}}$ values (x 100): $00\left(\mathrm{H}_{2} \mathrm{O}\right), 07$ (HOAc-6), 75 (BAW). UV (MeOH): $\lambda_{\max }=255,268,370 \mathrm{~nm}$. $(\mathrm{MeOH}+\mathrm{NaOAc}): \lambda_{\max }=254$, $276,375 \mathrm{~nm} \cdot\left(\mathrm{NaOAc}+\mathrm{H}_{3} \mathrm{BO}_{3}\right): \lambda_{\max }=272,388 \mathrm{~nm} .\left(\mathrm{MeOH}+\mathrm{AlCl}_{3}\right):$ $\lambda_{\max }=270,360,440 \mathrm{~nm} .\left(\mathrm{AlCl}_{3}+\mathrm{HCl}\right): \lambda_{\max }=258,400 \mathrm{~nm} \cdot{ }^{1} \mathrm{H}-\mathrm{NMR}$ $\left(\mathrm{DMSO}_{6}\right.$ ): $\delta 6.19$ (d, J=2.5, H-6), 6.4 (d, J=2.5, H-8), 7.64 (d, J=2.5,
H-2'), 6.88 (d, J=8.5, H-5'), 7.53 (dd, J=2.5 and 8.5, H-6'). ${ }^{13} \mathrm{C}-\mathrm{NMR}$ (DMSO-d $\mathrm{d}_{6}$ : $\delta 147.0$ (C-2), 135.8 (C-3), 176.2 (C-4), 160.5 (C-5), 99.2 (C-6), 164.0 (C-7), 93.7 (C-8), 156.4 (C-9), 103.5 (C-10), 122.2 (C-1'), 115.3 (C-2'), 145.1 (C-3'), 148.0 (C-4'), $115.6\left(\mathrm{C}^{-5} \mathbf{5}^{\prime}\right)$ and 120.2 (C-6').Ms (m/z): 300.8 [M- $-\mathrm{H}, 100 \%$, ion A], 299.8 [M- $\mathrm{M}_{2}, 28.3 \%$ ], 270.9 [ion $\mathrm{A}-\mathrm{C}_{2} \mathrm{H}_{6}, 8.9 \%$ ], 162.9 [ion $\mathrm{A}-\mathrm{C}_{7} \mathrm{H}_{6} \mathrm{O}_{3}, 10.1 \%$, ion $\mathrm{B}$ ] and 117.3 [ion $\mathrm{B}-$ $\mathrm{HCOOH}, 5.3 \%$ ]. Anal. Calcd for $\mathrm{C}_{15} \mathrm{H}_{10} \mathrm{O}_{7}$ (302.04): C, 59.61; H, 3.33; O, 37.06.Found: C, 59.30; H, 3.40; O, 37.30 .

Chlorogenic acid: $\mathrm{R}_{\mathrm{f}}$ values (x100): 67 (H2O), 65 (HOAC-6\%), 59 (BAW)UV (MeOH) $\lambda_{\max }(\mathrm{nm})(\mathrm{a}): 220,245,300,330(\mathrm{a})+\mathrm{NaOMe}$ $229,275,400 .{ }^{1} \mathrm{H}-\mathrm{NMR}$ Spectral Data $\left(\mathrm{DMSO}_{-} \mathrm{d}_{6}\right) \delta(\mathrm{ppm})$ Caffeic acid moiety :7.42 (d, J=16Hz, $\beta-\mathrm{H}), 7057.05$ (d, J=2Hz, 6-H), 6.96 (dd, J=7.5 $\mathrm{Hz}$ and $\mathrm{J}=2 \mathrm{~Hz}, 2-\mathrm{H}), 6.79(\mathrm{~d}, \mathrm{~J}=7.5 \mathrm{~Hz}, 3-\mathrm{H}), 6.19(\mathrm{~d}, \mathrm{~J}=16 \mathrm{~Hz}, \alpha-\mathrm{H})$. Quinic acid moiety: 5(m, 1'-H), 1.88 (m, 2'-H and 6'-H), 3.85 (m, 3'-H and $\left.5^{\prime}-\mathrm{H}\right), 3.5\left(\mathrm{~m}, 4^{\prime}-\mathrm{H}\right) .{ }^{13} \mathrm{C}-\mathrm{NMR}$ Spectral Data (DMSO-d $\left.{ }_{6}\right) \delta(\mathrm{ppm})$ Caffeic acid moity:126.1 (C-1), 115.2 (c-2), 144.9 (C-3), 148.5 (C-4), 116.29 (C-5), 121, 5 (C-6), 146.2 (C-7), 115.2 (C-7), 115.2(C-8), 116.5 (C-9) Quinicacid moiety: $76.6\left(\mathrm{C}-1^{\prime}\right) 68.6\left(\mathrm{C}-3^{\prime}\right), 71.8\left(\mathrm{C}-4^{\prime}\right), 71\left(\mathrm{C}-5^{\prime}\right)$, 180 (C-7'), signals of C-2'. 


\section{Results of Antibacterial Activity}

As we can see from the data in Figure 1; tha tmethanolic extract had different antibacterial activities of palm pollen.Antibacterial activity was done against six species pathogenic bacteria (Escherichia Coli, Klebsiella, Staphylococcus Epidermidis, Bacillus Cereus, Micrococcus Luteusand Staphylococcus Aureus), but it has a strong value at 22 $\mathrm{mm}$ inhibition zone with Staphylococcus Epidermidiswhich equal to antibiotic value with the same species.

\section{Results of Antifungal Activity}

Antifungal activity was done against two species pathogenic fungi (Candida Albicans, AspergillusNiger), Also we can see from the data in Figure 2; that the methanolic extract and ketoconazolehave the value with the two species.

\section{Results of Anti-tumor activity}

The methanolic extract of date palm pollen (Phoenix dactyliferaL) was tested against three human cell lines [HELA-1(Cervical carcinoma cell line), MCF7 (breast carcinoma cell line) and CACO (intestinal carcinoma cell line)], and IC50 value of the different cell lines of the methanolic extract of date palm pollen were reported in Figure 3.

\section{Conclusion}

The methanolic extract of (DPP) include on active chemical compounds (six phenolic compounds) which were more active towards six species pathogenic bacteria, two species fungi and last two cell lines ( MCF-7 and CACO ).

\section{References}

1. Copley MS, Rose PJ, Clapham A, Edwards DN, Horton MC, et al. (2001)
Detection of palm fruit lipids in archaeological pottery from Qasr lbrim, Egyptian Nubia. Proc Biol Sci 268: 593-597.

2. Miller CJ, Dunn EV, Hashim IB (2003) The glycaemic index of dates and date/ yoghurt mixed meals. Are dates 'the candy that grows on trees'? Eur J Clin Nutr 57: 427-430.

3. Al-Qarawi AA, Ali BH, Al-Mougy SA, Mousa HM (2003) Gastrointestinal transit in mice treated with various extracts of date (Phoenix dactylifera L.). Food Chem Toxicol 41: 37-39.

4. Anonymous (1985) The wealth of India (A dictionary of Indian raw materials and industrial products) Raw materials. (1stedn), Council of Scientific and Industrial Research, New Delhi.

5. Vyawahare N, Pujari R, Khsirsagar A, Ingawale D, Patil M, et al. (2009) Phoenix dactylifera: An update of its indegenous uses, phytochemistry and pharmacology. Journal of Pharmacology 7.

6. EI-Desoky GE, Ragab AA, Ismail SA, Kamal AE (1995) "Effect of palmpollen grains (Phoenix dactylifera) on sexhormones, proteins, lipids and liver functions." J. Agric. Sci.Mansoura Univ. 20: 4249-4268.

7. Nawwar MAM, Hussein SAM, Buddrus J, Linscheid M (1994) " Tamarixellagic acid, an ellagitannin from the galls of Tamarix aphylla", Phytochemistry, 35: 1349.

8. Harborne J B (1982) "The Flavonoids: Advances in Research", Chapman and Hall. London. Phytochemical Analysis 6: 55.

9. Abd El Azim MHM, El-Mesallamy, AMD, El-Gerby M, Awad A (2014) AntiTumor, Antioxidant and Antimicrobial and the Phenolic Constituents of Clove Flower Buds (Syzygium aromaticum). J Microbial Biochem Technol.S8

10. Biglari F, Abbas FM, AlKarkhi, Azhar ME, (2008) Antioxidant activity and phenolic content of various date palms (Phoenix dactylifera) fruits from Iran Food Chemistry. 107: 1636-1641.

11. Skehan P, Storeng R, Scudiero D, Monks A, McMahon J, et al. (1990) New colorimetric cytotoxicity assay for anticancer-drug screening. J Natl Cancer Inst 82: 1107-1112. 